ISSN 2073-4441

www.mdpi.com/journal/water

Article

\title{
AnnAGNPS Model Application for Nitrogen Loading Assessment for the Future Midwest Landscape Study
}

\section{Yongping Yuan ${ }^{1, *}$, Megan H. Mehaffey ${ }^{1}$, Ricardo D. Lopez ${ }^{1}$, Ronald L. Bingner ${ }^{2}$, Randy Bruins ${ }^{3}$, Caroline Erickson ${ }^{1}$ and Michael A. Jackson ${ }^{1}$}

1 U.S. Environmental Protection Agency Office of Research and Development, Environmental Sciences Division, 944 East Harmon Ave., Las Vegas, NV 89119, USA;

E-Mails: Mehaffey.megan@epa.gov (M.H.M.); Lopez.ricardo@epa.gov (R.L.);

Erickson.caroline@epa.gov (C.E.); Jackson.michael@epa.gov (M.A.J.)

2 USDA-ARS Watershed Physical Processes and Water Quality \& Ecology Research Unit, National Sedimentation Laboratory, 598 McElroy Dr., Oxford, MS 38655, USA;

E-Mail: ron.bingner@ars.usda.gov (R.L.B.)

3 U.S. Environmental Protection Agency Office of Research and Development, Ecological Exposure Research Division, 26 W. Martin Luther King Dr., Cincinnati, OH 45268, USA;

E-Mail: Bruins.randy@epa.gov (R.B.)

* Author to whom correspondence should be addressed; E-Mail: yuan.yongping@epa.gov; Tel.: +1-702-798-2111; Fax: +1-702-798-2208.

Received: 15 November 2010; in revised form: 14 December 2010 / Accepted: 1 February 2011 / Published: 17 February 2011

Abstract: The Future Midwest Landscape (FML) project is part of the US Environmental
Protection Agency (EPA)'s new Ecosystem Services Research Program, undertaken to
examine the variety of ways in which landscapes that include crop lands, conservation
areas, wetlands, lakes, and streams affect human well-being. The goal of the FML project
is to quantify current and future ecosystem services across the region and to examine
changes expected to occur as a result of the growing demand for biofuels. This study is one
of several pilots taking place under the umbrella of the FML research project. In this study,
the USDA Annualized Agricultural Non-Point Source Pollution (AnnAGNPS) model was
applied to the East Fork Kaskaskia River watershed ( $\left.289.3 \mathrm{~km}^{2}\right)$ located in the Kaskaskia
River Basin within the Upper Mississippi River Basin in Illinois. The effect of different
spatial resolutions on model performance was investigated by comparing the observed
runoff with the AnnAGNPS simulated results. Alternative future scenarios such as meeting 
future biofuel target were also simulated and analyzed. All delineations of the study area (coarser to finer) produced satisfactory results in simulating monthly and annual runoff. However, the size of the delineation does impact the simulation results. Finer delineations better represented the actual landscape and captured small critical areas that would be homogenized in coarser delineation. Those small critical areas are important to target to achieve maximum environment benefit. Simulations of alternative future scenarios showed that as corn production increases to meet future biofuel needs, total nitrogen loss increases. For this watershed, total $\mathrm{N}$ loss would be more than doubled if converting all corn/soybean rotation $(15,871.2 \mathrm{ha})$ to continuous corn comparing with the base year total $\mathrm{N}$ loss which is $11.2 \mathrm{~kg} / \mathrm{ha}$. Conservation practices are needed to reduce total nitrogen loss from the watershed. This study provides an important foundation for the larger FML region modeling effort by addressing challenging FML landscape modeling issues such as model selection, need for further model development, and spatial resolution.

Keywords: Future Midwest Landscape study; AnnAGNPS; watershed modeling; runoff and nitrogen simulation

\section{Introduction}

The Future Midwest Landscape (FML) study is part of the US Environmental Protection Agency (EPA)'s new Ecosystem Services Research Program, undertaken to examine the variety of ways in which landscapes that include crop lands, conservation areas, wetlands, lakes, and streams affect human well-being. The goal of the FML project is to quantify current ecosystem services across the Midwest region and to examine changes expected to occur as a result of the growing demand for biofuels (particularly increased corn production in this study).

Nitrogen $(\mathrm{N})$ losses to surface waters are of great concern on both national and regional scales. Scientists have concluded that large areas of hypoxia in the northern Gulf of Mexico are due to excessive $\mathrm{N}$ derived primarily from agricultural runoff via the Mississippi River [1-5]. Loss of $\mathrm{N}$ to surface waters is also a problem on a local level. Excess nitrate in drinking water can be toxic to humans, and treatment is expensive when nitrate in surface water supplies exceed EPA threshold levels [6].

Nitrogen losses from Midwest corn/soybean cropland have been identified as one of the major sources of $\mathrm{N}$ in streams and to the Gulf of Mexico [7,8]. With the growing demand for biofuel, there is an urgent need to quantify potential increased $\mathrm{N}$ losses from the Midwest cropland due to the increased corn production. This information is particularly important for policy makers to take timely actions such as increased conservation practices to reduce $\mathrm{N}$ loads to the Gulf of Mexico. Ways of reducing $\mathrm{N}$ loads proposed by scientists include better management of the $\mathrm{N}$ fertilization rates and timing; and creation of wetlands and riparian buffers [7-9].

Monitoring programs are often used to evaluate land management effects on non-point source pollution [10]. Long-term monitoring better reflects multi-year climatic variability and helps assure that a range of events and conditions are covered [11,12]. Because long-term monitoring is expensive 
and often limited by personnel and financial resources, short-term monitoring with complimentary simulation modeling may be used as an alternative for watershed evaluation.

Models such as the USDA-Agricultural Research Service (ARS) Annualized Agricultural NonPoint Source Pollution model (AnnAGNPS) [13] have been developed to aid in the evaluation of watershed response to agricultural management practices. Through a continuous simulation of runoff, sediment and pollutant loadings from watersheds, conservation programs can be evaluated. Many studies have demonstrated AnnAGNPS's capability in predicting runoff, sediment and $\mathrm{N}$ losses on various time scales [14-19]. However, all those AnnAGNPS applications were performed at relatively small watersheds, for which the watershed can be delineated as detail as needed to account for the variation of land-use and soil as well as for the need of implementing conservation practices while remaining computationally feasible. The FML study area includes 12 states of the USA, and to apply AnnAGNPS at larger watersheds, the level of detail a model represents in a watershed has to be optimized because of the limitation on computational power of a computer. Thus, there is a need to evaluate the level of spatial detail a model represents on the accuracy of model results.

The overall objectives of this study were: (1) to explore the applicability of the AnnAGNPS model on a large scale through exploring the model spatial resolutions and accuracy; (2) to apply the model to current and future landscape scenarios to look at potential $\mathrm{N}$ loading changes caused by increased corn production.

\section{Materials and Methods}

\subsection{AnnAGNPS Model Description}

AnnAGNPS is an advanced simulation model developed by the USDA-ARS and Natural Resource Conservation Services (NRCS) to help evaluate watershed response to agricultural management practices [13]. It is a continuous simulation, daily time step, pollutant loading model designed to simulate water, sediment and chemical movement from agricultural watersheds [13]. The AnnAGNPS model evolved from the original single event AGNPS model [20], but includes significantly more advanced features than AGNPS. The spatial variability of soils, land-use, and topography within a watershed can be determined by dividing the watershed into many user-specified, homogeneous, drainage-area-determined cells. From individual cells, runoff, sediment and associated chemicals can be predicted from precipitation events that include rainfall, snowmelt and irrigation. AnnAGNPS simulates runoff, sediment, nutrients and pesticides leaving the land surface and being transported through the watershed channel system to the watershed outlet and has the capability to identify the sources of pollutants at their origin and track them as they move through the watershed system. The complete suite of AnnAGNPS model, which include programs, pre and post-processors, technical documentation, and user manuals, are currently available at http://www.ars.usda.gov/Research/ docs.htm?docid=5199.

The hydrology components considered within AnnAGNPS include rainfall, interception, runoff, evapotranspiration (ET), infiltration/percolation, subsurface lateral flow and drainage. The runoff from each cell is calculated using the SCS curve number method [21]. The modified Penman equation $[22,23]$ is used to calculate the potential ET, and the actual ET is represented as a fraction of 
the potential ET. The fraction is a linear function of soil moisture between wilting point and field capacity. For percolation, only the downward drainage of soil water by gravity is calculated [13]. Lateral flow is calculated using the Darcy equation, and subsurface drainage is calculated using the Hooghoudt's equation [24-26].

The AnnAGNPS model calculates a daily mass balance within each cell for soil moisture, nitrogen $(\mathrm{N})$, phosphorus (P), organic carbon (OC), and pesticides. Plant uptake of nutrients, fertilization, residue decomposition, mineralization, and transport are major factors considered to determine the fate of nutrients in the watershed. Both soluble and sediment adsorbed nutrients are considered by the model.

Input data available for AnnAGNPS model are presented in Figure 1. Required input parameters include climate data, watershed physical information, and land management operations such as planting, fertilizer and pesticide applications, cultivation events, and harvesting. Daily climate information is required to account for temporal variation in weather and multiple climate files can be used to describe the spatial variability of weather. Output files can be produced to describe runoff, sediment and nutrient loadings on a daily, monthly, or yearly basis. Output information can be specified for any desired watershed source location such as specific cells, reaches, feedlots, or point sources. Additional information describing AnnAGNPS can be found in [13].

Figure 1. AnnAGNPS input data sections.

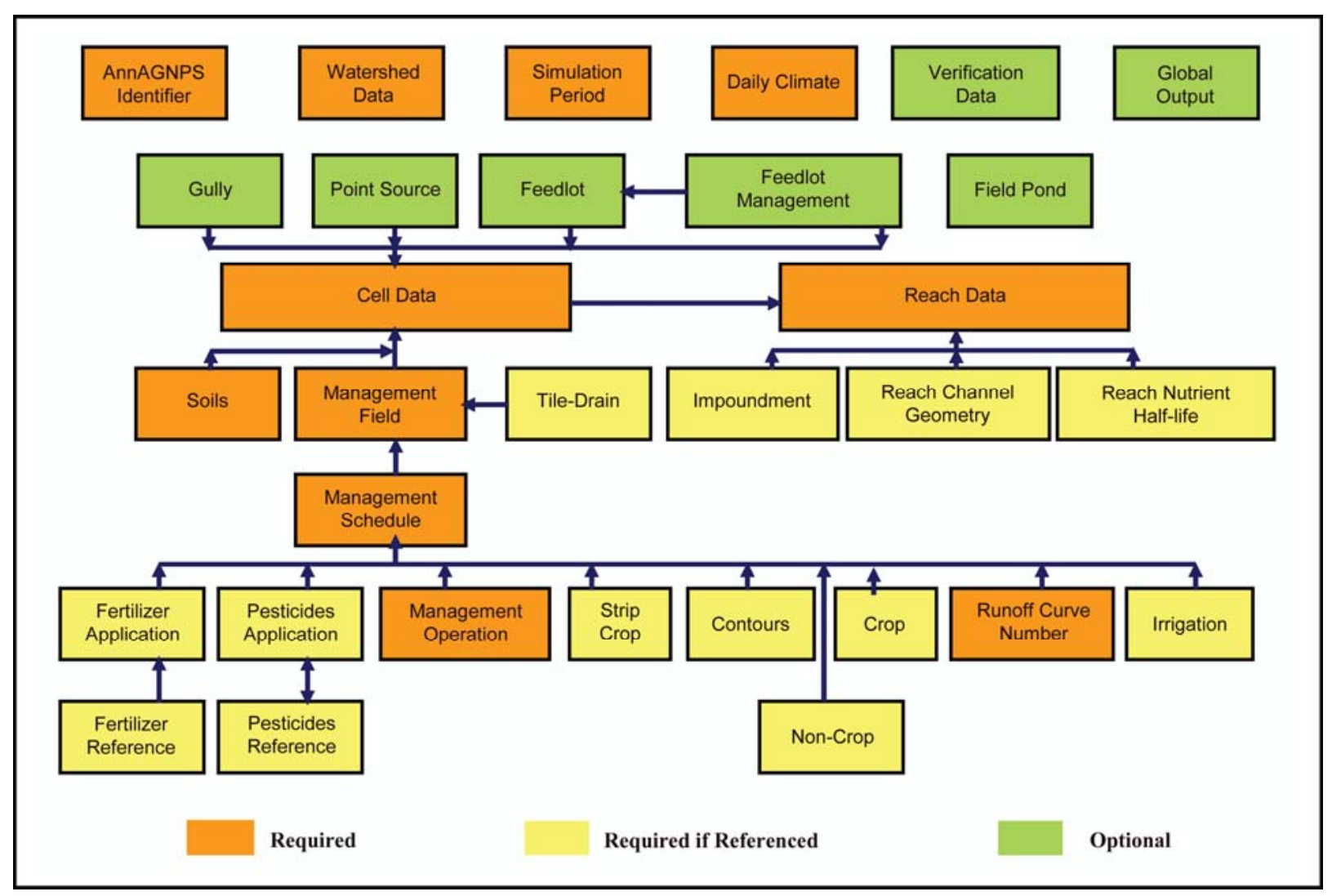

\subsection{USGS Stream Gauge Station 05592900 and Data Summary}

The USGS stream gauge station 05592900 East Fork Kaskaskia River near Sandoval $\left(38^{\circ} 41^{\prime 2} 20^{\prime \prime}\right.$ and $\left.89^{\circ} 06^{\prime} 00^{\prime \prime}\right)$ is located in Marion County, Illinois and is a part of the Kaskaskia River Basin 
(Figure 2) which directly drains to the Mississippi River. The USGS 05592900 drains $289.3 \mathrm{~km}^{2}$, with elevations ranging from $142 \mathrm{~m}$ to $194 \mathrm{~m}$ above sea level. The study area has a dominant land-use of agriculture (61\%), and major crops are corn/soybeans. The other land-use includes forest (26\%), urban $(9 \%)$, wetland $(3 \%)$ and barren $(1 \%)$.

Figure 2. Location of the watershed.

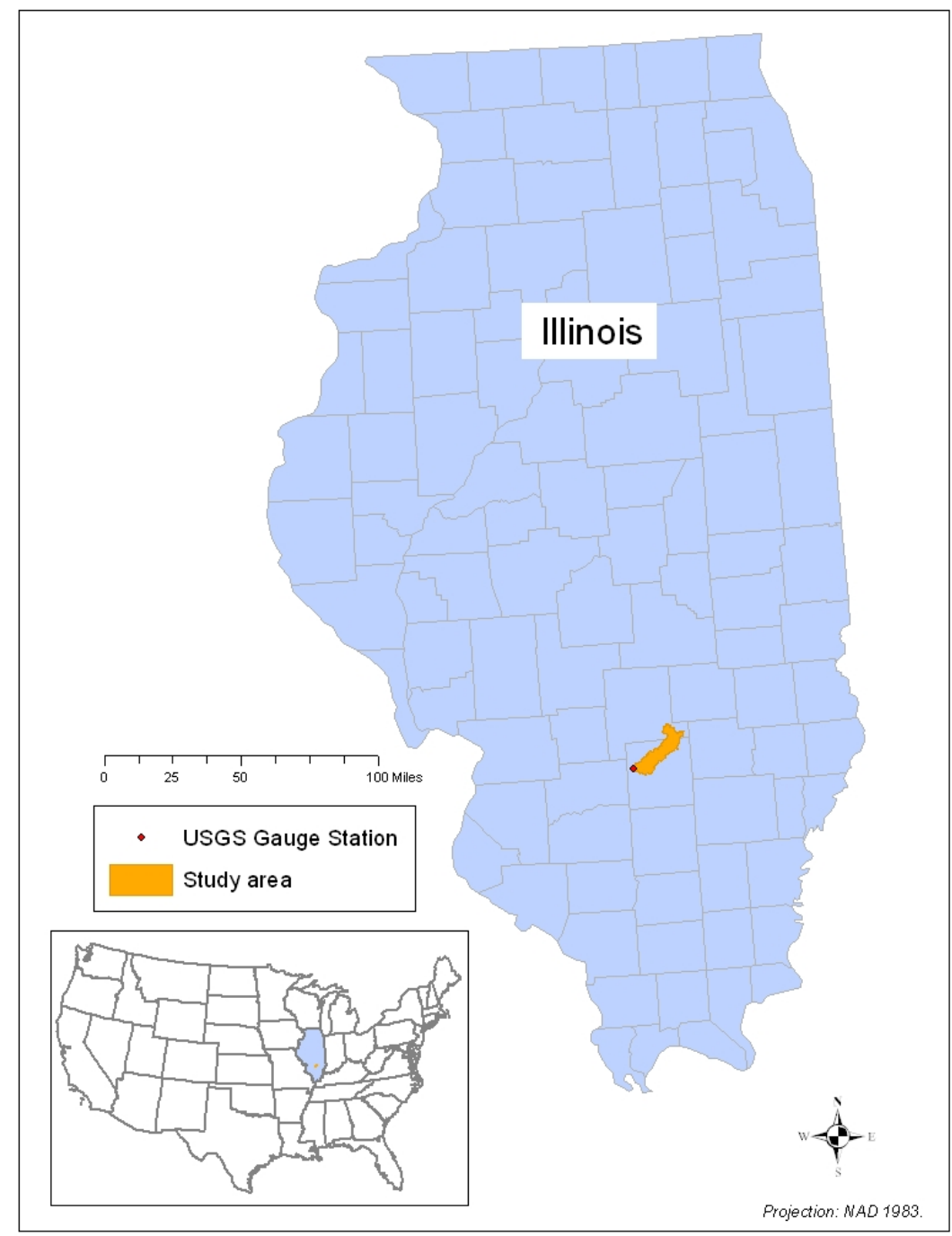

Daily, monthly and annual stream discharge at station 05592900 was downloaded from the U.S. Geological Survey (USGS) National water Information System (NWIS). The station has a complete record from 1980 to 2006. The USGS Water quality data were obtained from the USGS National Stream Quality accounting Network (NASQAN) for the period of 1980 to 2006. However, water quality measurements are not as frequent as stream flow, usually one measurement per month. Baseflow Filter Program [27,28] was used to separate baseflow from total streamflow. To estimate pollutant mass loadings, flow volume and pollutant concentrations are needed. Since pollutant concentrations were not available on a daily basis, the USGS (2004) LOADEST program [29] were used to estimate pollutant mass loadings. The input to the LOADEST program [29] is pollutant concentrations and discharge volume on the day when pollutant concentrations were measured. The 
LOADEST program produces monthly and annual pollutant mass loadings. There are several statistical regression methods available in the LOADEST program [29] for pollutant mass loading estimation, and details can be found in the LOADEST documentation. For this case, all statistical regression methods produced similar results. Pollutant mass loadings then were normalized by dividing monthly or annual load by the drainage area and expressed as mass per area. Monthly and annual stream discharge together with LOADEST estimated pollutant loadings were used to evaluate the performance of AnnAGNPS.

\subsection{AnnAGNPS Input Preparation}

Using the GIS digital data layers of digital elevation model, soils, and land-use, a majority of the data input requirements of AnnAGNPS were developed by using a customized ArcView GIS interface [13]. Inputs developed from the ArcView GIS interface include physical information of the watershed and subwatershed (AnnAGNPS cell), such as boundary and size, land slope and slope direction, and channel reach (AnnAGNPS reach) descriptions. The ArcView GIS interface also assigned a soil and land-use type to each cell by using the generated subwatershed and the soil and land-use GIS data layers. Additional steps to provide the model with the necessary inputs included developing the soil layer attributes to supplement the soil spatial layer, establishing the different crop operation and management data, and providing channel hydraulic characteristics. Those inputs can be organized using the AnnAGNPS Input Editor [13], a graphical user interface designed to aid users in selecting appropriate input parameters. Management information includes various field management operations such as planting, cultivation, fertilization, pesticides and harvesting, much of which can be obtained from RUSLE [30] databases or from actual activities implemented. Climate data for AnnAGNPS simulation can be historically measured, synthetically generated using the climate generator program [31], or created through a combination of the two.

\subsubsection{AnnAGNPS cell and reach data}

AnnAGNPS cell and reach parameters were produced with the customized ArcView GIS interface which uses the TOPAZ (TOpographic PArameteriZation) software package [32]. TOPAZ is primarily designed to assist with topographic evaluation and watershed parameterization in support of hydrologic modeling and analysis. The DEM processing in TOPAZ is based on the downslope flow routing and the critical source area (CSA) concept. The CSA concept defines the channels draining the landscape as those raster cells that have an upstream drainage area greater than a threshold drainage area (critical source area). The CSA value defines a minimum drainage area below which a permanent channel is defined [32,33]. TOPAZ requires input of the DEM of the watershed, DEM characteristics, DEM processing options and data output options. Most important for hydrographic landscape segmentation and channel stream network generation are two user-provided network parameters: the CSA and the minimum source channel length (MSCL). For example, as the CSA parameter is increased drainage density of the generated network decreases, and as the MSCL parameter is increased short source channels (1st order channels) are removed. The user can estimate the CSA and MSCL parameters from maps or field surveys, or select their value to fit the scale and resolution of the particular application under consideration. Fine tuning of these values may be necessary to reproduce 
observed spatial variability. Usually, the finer the delineation is, the better characterization of the variation of land-use and soil. However, a continuous trend may not be obtained as the watershed delineation becomes finer and finer because the land-use and soil assigned to each subwatershed is the dominant land-use and soil which could be changed from one watershed delineation to another. To evaluate the cell sizes as subwatersheds on AnnAGNPS model hydrologic and water quality predictions, various combinations of CSA and MSCL were used for watershed delineation (Table 1), and numbers of cells and reaches generated from each combination of CSA and MSCL values are also listed in Table 1.

Table 1. Cell and reach numbers within the study area using different CSA and MSCL values.

\begin{tabular}{|c|c|c|c|c|}
\hline $\begin{array}{c}\text { Type of } \\
\text { delineation }\end{array}$ & $\begin{array}{c}\text { *CSA parameter } \\
\text { (ha) }\end{array}$ & $\begin{array}{c}\text { *MSCL parameter } \\
\text { (meters) }\end{array}$ & $\begin{array}{c}\text { Number } \\
\text { of cells }\end{array}$ & $\begin{array}{c}\text { Number } \\
\text { of reaches }\end{array}$ \\
\hline 1 & 500 & 2,000 & 48 & 20 \\
\hline 2 & 200 & 500 & 188 & 76 \\
\hline 3 & 100 & 200 & 367 & 148 \\
\hline 4 & 20 & 40 & 1,728 & 721 \\
\hline
\end{tabular}

* CSA is Critical Source Area, and MSCL is the Minimum Source Channel Length. The total area for the watershed is 28707 ha.

\subsubsection{Soils}

Detained soil information was obtained from the USDA-NRCS Soil Survey Geographic (SSURGO) Database [34]. SSURGO provides most of soil parameters needed for AnnAGNPS simulation, such as soil texture, erosive factor, hydraulic properties, $\mathrm{pH}$ value, and organic matter. Information on soil nutrient contents was estimated based on soil organic matter [35]. Geographical Information System (GIS) soil maps were used in conjunction with the subwatershed maps to determine the predominant soil assigned to each AnnAGNPS cell. Soil parameters were formatted using the AnnAGNPS Input Editor.

\subsubsection{Land-use and field management}

The characterization of the watershed land-use, crop operation, and management during the simulation period was critical in providing estimates of the pollutant loadings. AnnAGNPS has the capability of simulating watershed conditions with changing land-use and crop management over the simulation period. However, it was very difficult, at this watershed scale, to characterize the annual changes, including land-use and field management practices, occurring in the watershed. To achieve the objectives of this study, four evaluation schemes were considered during input file development of land-use and field management: (1) model validation; (2) model simulation to represent the base year (BY) of crop type and rotation, and management; (3) model simulation of the 2022 biofuel targets (BT) scenarios which represents future land-use change to meet bio-fuel production target; and (4) model simulation of the 2,022 multiple services (MS) scenario which evaluates the impact of best management practices and/or conservation programs on water quality and quantity. 
Since monitored runoff and water quality data from the USGS gauging station-5592900 were available from 1980-2006 [36], actual records of field operation and crop management from 1980 to 2006 should be used to develop land-use and management schedules for model performance evaluation. However, this information was not available at the watershed scale.

To evaluate the impact of future increased corn production to meet ethanol demand, a base year land-use/land cover was needed. Thus, the first step involved was to develop the spatially-explicit agricultural data which includes information on crop type and rotation. The USGS 2001 National Land Cover Database (NLCD) was selected as a basis for base year data layer. It was obvious that the LANDSAT derived single year NLCD would not yield the desired level of detail for the AnnAGNPS modeling. For example, corn, soybeans and wheat are not differentiated in the NLCD data, nor does it provide crop rotation information. For this reason, it was necessary to involve a many image or multi-temporal approach in identifying crop types. Thus, the USDA National Agriculture Statistical Survey (NASS) Cropland Data Layer (CDL) was collected for years of 2004-2007 to expand the "Single cultivated crops" land-use within the NLCD into multiple cropping types and rotational information.

Base year land-use information for the study area is listed in Table 2. This land-use was used for BY scenario simulation. Base year land-use was repeated for simulation of 1980 to 2006 for model evaluation because of the difficulties in characterizing land-use changes from 1980-2006. Land-uses of different delineations for AnnAGNPS simulations for validation are also listed in Table 2. The BT scenarios are these expected to result given currently existing law and policy, plus the standards established by the Energy Independence and Security Act of 2007 (EISA; Public Law 110-140). These scenarios anticipate a steady increase in corn production, and by 2022, the EISA goals are met. Therefore, corn area was gradually increased for BT scenarios based on the base year GIS land-use listed in Table 2. The MS scenarios are those which can be used to evaluate how best management practices and/or conservation programs might be implemented to improve ecosystems services, reducing $\mathrm{N}$ loadings to streams in this case. Thus, split fertilizer application was evaluated based on the final BT land-use because the model is limited in simulating the processes of wetland and riparian zones.

For crop management practices, RUSLE crop management database downloaded at http://fargo.nserl.purdue.edu/rusle2_dataweb/RUSLE2_Index.htm was used to develop the AnnAGNPS Management Schedule Data Section for the base year. The tillage practice information is available at the county level from the Conservation Technology Information Center (CTIC-http://www.ctic.purdue.edu/) using the regional data from 2004. The data report overall percentage of tillage types by county, not exact field-by-field. Therefore, no tillage was assumed for all simulations. Nitrogen applied for major crops corn, soybean and wheat are listed in Table 3. 
Table 2. Land-use defined by the final GIS land-use layer and by AnnAGNPS cells of different delineations.

\begin{tabular}{|c|c|c|c|c|c|c|c|}
\hline \multirow{2}{*}{ Land-use type } & \multicolumn{6}{|c|}{$\begin{array}{c}\text { Distribution of land-use assigned to AnnAGNPS Cells } \\
\text { for the 4 delineations (ha) as shown in Table 1 }\end{array}$} & \multicolumn{2}{c|}{$\begin{array}{c}\text { Land-use from } \\
\text { GIS layer }\end{array}$} \\
\cline { 2 - 8 } & 1 & 2 & 3 & \multicolumn{2}{|c|}{4} & Area (ha) & Percent \\
\hline Corn & 0 & 0 & 1.4 & 14.6 & $0.1 \%$ & 780.7 & $2.7 \%$ \\
\hline Corn/soybean & $16,582.8$ & $18,269.5$ & $16,529.9$ & $15,871.2$ & $55.3 \%$ & $11,665.6$ & $40.6 \%$ \\
\hline Corn/wheat & 0 & 0 & 0 & 0 & $0.0 \%$ & 80.7 & $0.3 \%$ \\
\hline Soybean & 0 & 0 & 0 & 130.3 & $0.5 \%$ & 613.1 & $2.1 \%$ \\
\hline Soybean/other & 0 & 190.0 & 206.8 & 611.1 & $2.1 \%$ & $1,704.9$ & $5.9 \%$ \\
\hline Soybean/wheat & 0 & 0 & 160.4 & 277.5 & $1.0 \%$ & 666.5 & $2.3 \%$ \\
\hline Wheat & 0 & 0 & 0 & 0 & $0.0 \%$ & 95.9 & $0.3 \%$ \\
\hline Grain & 0 & 0 & 3.5 & 19.0 & $0.1 \%$ & 239.9 & $0.8 \%$ \\
\hline Pasture/hay & 0 & 43.7 & 0 & 244.3 & $0.9 \%$ & 896.0 & $3.1 \%$ \\
\hline Fallow/idle & 0 & 292.4 & 264.1 & 603.1 & $2.1 \%$ & 721.3 & $2.5 \%$ \\
\hline Barren & 0 & 0 & 8.5 & 0.6 & $0.0 \%$ & 209.3 & $0.7 \%$ \\
\hline Forest & $12,124.9$ & $9,687.0$ & $11,075.0$ & $9,862.4$ & $34.4 \%$ & $7,555.6$ & $26.3 \%$ \\
\hline Developed & 0 & 215.1 & 448.0 & 870.9 & $3.0 \%$ & $2,637.7$ & $9.2 \%$ \\
\hline Wetland & 0 & 0 & 0 & 0 & $0.0 \%$ & 11.3 & $0.0 \%$ \\
\hline Flood plain & 0 & 10.1 & 10.1 & 96.1 & $0.3 \%$ & 693.4 & $2.4 \%$ \\
\hline Open water & 0 & 0 & 0 & 106.6 & $0.4 \%$ & 136.0 & $0.5 \%$ \\
\hline Total & $28,707.7$ & $28,707.7$ & $28,707.7$ & $28,707.7$ & $100 \%$ & $28,707.7$ & $100 \%$ \\
\hline
\end{tabular}

Table 3. Fertilizer application for BY and BT simulations.

\begin{tabular}{|c|c|}
\hline Crop name & Nitrogen application rate (kg/ha.) \\
\hline Corn & 165.3 \\
\hline Soybean & 4.5 \\
\hline Wheat & 115.5 \\
\hline
\end{tabular}

* All fertilizers were one time application and applied before planting.

\subsubsection{Climate information}

Daily maximum, minimum and dew point temperature, precipitation, sky cover, and wind speed are needed to account for temporal variation in weather. This data can be historically measured, estimated using the climate generator program-GEM [31,37], or supplied to AnnAGNPS using a combination of the two methods. For this study, the climate file has to be developed to serve all simulation purposes as discussed above. Therefore, several steps were involved in building climate files to evaluate the model performance, BY scenario simulation, BT and MS scenarios simulation of the watershed. Recognizing the need for long-term evaluation of conservation practices, a 30-year weather file representing 1977 to 2006 was first produced using the GEM program for the long-term conservation practice assessment. To develop a climate file to evaluate the model performance, information from National Oceanic and Atmospheric Administration (NOAA) weather stations within 100 miles of study area was collected and analyzed. Only one climate station was found in the study area. Missing records from this weather station were interpolated using the weather data from neighborlyhood weather stations and 
Parameter-elevation Regressions on Independent Slopes Model (PRISM) [38]. The inverse distance-weighted (IDW) interpolation method was used. Thus, the second climate file was developed by modifying the 30-year synthetic weather file using the climate information obtained from NOAA. The climate information obtained from NOAA was used to replace generated maximum and minimum temperature, and precipitation from 1977 to 2006. The rest of the weather parameters have a minor impact on the results, so no additional measured weather parameters were used.

\subsection{Model Evaluation}

The Nash-Sutcliffe coefficient of efficiency [39], the relative error, the Willmott index of agreement 'd' [40] and visual data analysis were used to evaluate the model's performance. The Nash-Sutcliffe coefficient of efficiency (NSE) ranges from minus infinity to one, with one indicating the model is perfect [39]. The NSE is computed as shown in equation 1:

$$
N S E=1-\left[\frac{\sum_{i=1}^{n}\left(Y_{i}^{\text {obs }}-Y_{i}^{\text {sim }}\right)^{2}}{\sum_{i=1}^{n}\left(Y_{i}^{\text {obs }}-Y^{\text {mean }}\right)^{2}}\right]
$$

The relative error (RE) is the ratio between the total difference and the total observed value, and it ranges from minus one to infinity. Zero indicates that there is no difference between model simulation and field observation. The smaller the absolute value of a relative error, the better performance of the model is. The index of agreement ' $d$ ' was developed by Willmott [40] as a standardized measure of the degree of model prediction error and varies between 0 and 1 . A computed value of 1 indicates a perfect agreement between the measured and predicted values, and 0 indicates no agreement at all [40]. The index of agreement ' $d$ ' can be calculated as shown in equation 2 :

$$
d=1-\left[\frac{\sum_{i=1}^{n}\left(Y_{i}^{\text {obs }}-Y_{i}^{\text {sim }}\right)^{2}}{\sum_{i=1}^{n}\left(\left|Y_{i}^{\text {sim }}-Y^{\text {mean }}\right|+\left|Y_{i}^{\text {obs }}-Y^{\text {mean }}\right|\right)^{2}}\right]
$$

where $Y_{i}{ }^{\text {obs }}$ is the ith observation for the constituent being evaluated, $Y_{i}{ }^{\text {sim }}$ is the ith simulated value for the constituent being evaluated, $\mathrm{Y}^{\text {mean }}$ is the mean of observed data for the constituent being evaluated, and $n$ is the total number of observations. The visual analysis was straightforward through the inspection of the graphs.

To address how resolution would affect the performance of the model, Simulation results from different delineations resulted from various combinations of CSA and MSCL values were compared with the observed data from the USGS gauging station. The Nash-Sutcliffe coefficient (NSE), relative error (RE) and the index of agreement ' $d$ ' were computed for all delineations.

\subsection{Model Simulations of BY, BT and MS Scenarios}

After AnnAGNPS simulations were evaluated based on the observed data from the USGS gauging station 0559200 at East Fork Kaskaskia River, AnnAGNPS simulations were performed to estimate 
runoff and nutrient transport in the watershed for the BY scenario. Results from this simulation were used as a baseline or a reference for additional simulations of BT scenarios to meet the biofuel target as well as to evaluate the impact of biofuel production on water quality. For BT scenario simulations, land-use (Table 2) in the entire study area was first evaluated, then soybean was converted to corn first (BT_1). Additional corn production is realized through following conversion sequence: one third of the corn/soybean rotation was converted to continuous corn (BT_2) based on BT_1 (130.3 ha soybean and $5290.4 \mathrm{corn} /$ soybean rotation converted to corn); two third of the corn/soybean rotation was converted to continuous corn (BT_3), and entire corn/soybean rotation was converted to continuous corn (BT_4). The last one was converting all fallow/idle land to corn production (BT_5) based on BT_4. It was assumed that the study area has achieved its maximum potential for corn production by now. All fertilizer was applied in spring before planting.

The final scenario, MS simulations were performed to look for strategies to reduce $\mathrm{N}$ loadings from the study area because of the concerns with water quality of the Mississippi river and hypoxia of the Gulf of Mexico. Generally, fertilizer management is one of the important ways to reduce $\mathrm{N}$ losses from cropland. Fertilizer management includes matching nutrient application rates with crop needs, and timing fertilizer applications to meet the plants' nutrient uptake capacity. For this study, the application rates are assumed to match crop needs. Therefore, split $\mathrm{N}$ application was evaluated. Instead of one time application, $\mathrm{N}$ was applied three times based on corn $\mathrm{N}$ needs during corn growth period as listed in Table 4 [41]. For nutrients that are attached to soil particles, conservation practices that reduce sediment loss would also reduce nutrient loss. For this study, it was assumed that conservation practices that reduce sediment loss are in place for all scenario simulations.

Table 4. Nitrogen split applications for corn for MS simulations.

\begin{tabular}{|c|c|c|}
\hline Application & Nitrogen application rate (kg/ha) & Comments \\
\hline 1 & 21.3 & Before planning \\
\hline 2 & 94.2 & 25 days after first application \\
\hline 3 & 32.1 & 25 days after second application \\
\hline
\end{tabular}

\section{Results and Discussion}

AnnAGNPS simulated monthly runoff and annual runoff from delineation 4 (CSA $=20$-ha, MSCL $=40-\mathrm{m}$ ), and the observed monthly runoff and annual runoff at the USGS gauging station are displayed in Figures 3 and 4. Calculated NSE, RE and the index of agreement ' $d$ ' are also shown in Figures 3 and 4. AnnAGNPS simulated monthly runoff and annual runoff from other delineations (Figures not shown) were also compared with the observed monthly runoff and annual runoff at the USGS gauging station, and the calculated NSE, RE and the index of agreement ' $d$ ' are given in Table 5. Sediment data were not available from the USGS monitored station to evaluate AnnAGNPS simulated sediment. AnnAGNPS simulated annual total $\mathrm{N}$ and computed annual total $\mathrm{N}$ using the observed daily stream flow and observed monthly total $\mathrm{N}$ concentration are displayed in Figure 5 . NSE, RE and the index of agreement were not calculated because $\mathrm{N}$ concentration at a monthly interval is not good enough for model calibration and evaluation [42]. Results of BY simulation from different delineations are given in Table 6. Results from alternative scenario simulations based on 
delineation 4 are given in Table 7. Loadings refer to the amount of $\mathrm{N}$ that move through stream channels and reach the watershed outlet (the USGS gauging station). Total $\mathrm{N}$ loss from delineations 4 and 1 were displayed in Figure 6 to show how cell size affects the spatial variation of total $\mathrm{N}$ loss. Total N loss from BT_5 is displayed in Figure 7.

Figure 3. Comparison of observed and simulated monthly runoff (from delineation 4) for the period of 1980 to 2006 .

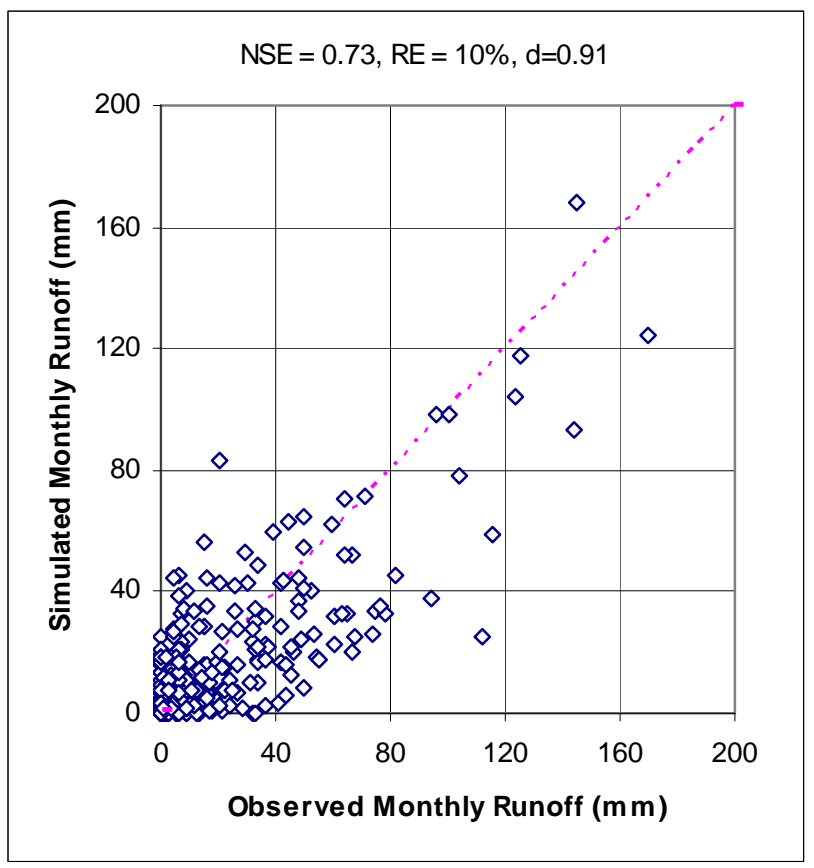

Figure 4. Comparison of observed and simulated Annual runoff (from delineation 4) from the USGS gauging station.

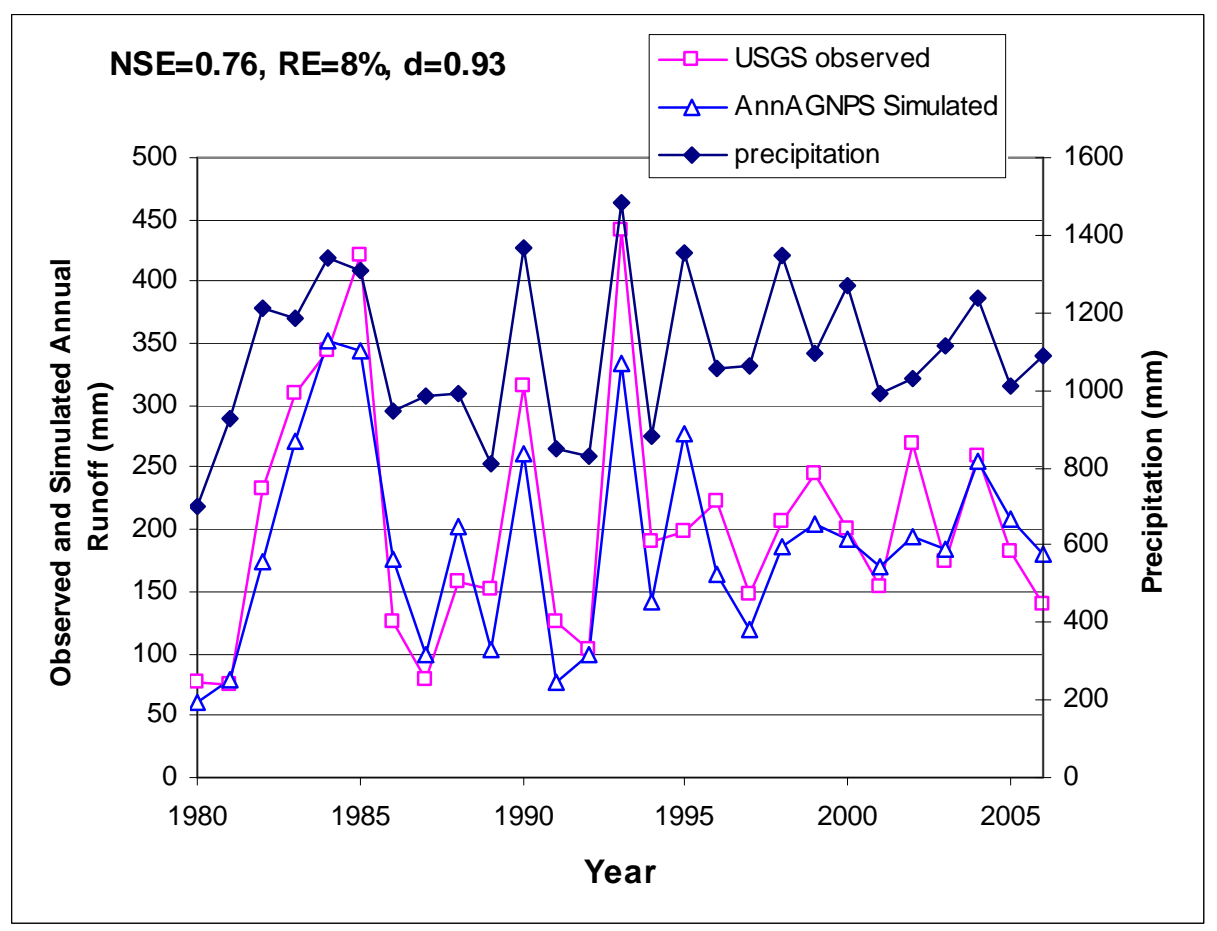


Figure 5. Comparison of observed and simulated total nitrogen load (from delineation 4) from the USGS gauging station.

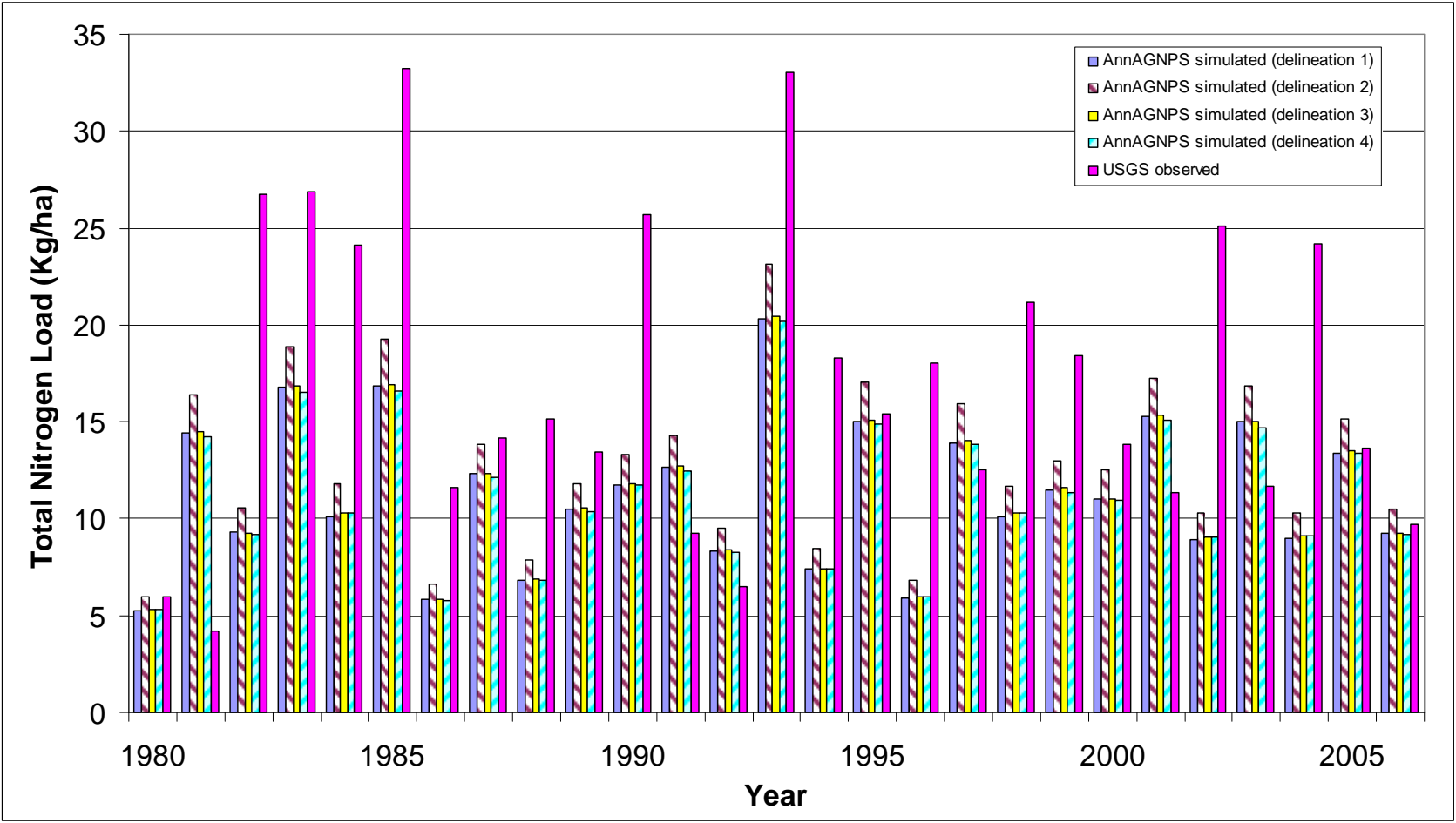

Table 5. Monthly and Annual runoff comparisons for different delineations.

\begin{tabular}{|c|c|c|c|c|c|c|c|}
\hline \multirow{2}{*}{$\begin{array}{c}\text { Type of } \\
\text { delineation }\end{array}$} & \multicolumn{3}{|c|}{ Monthly comparison } & \multicolumn{2}{c|}{ Annual comparison } & Number \\
\cline { 2 - 8 } & NSE & RE(\%) & $\mathrm{d}$ & NSE & RE $(\%)$ & $\mathrm{d}$ & of cells \\
\hline 1 & 0.73 & 16 & 0.91 & 0.76 & 8 & 0.93 & 48 \\
\hline 2 & 0.73 & 8 & 0.92 & 0.76 & 8 & 0.93 & 188 \\
\hline 3 & 0.73 & 13 & 0.91 & 0.76 & 8 & 0.93 & 367 \\
\hline 4 & 0.73 & 10 & 0.91 & 0.76 & 8 & 0.93 & 1728 \\
\hline
\end{tabular}

Table 6. Annual average over the entire watershed based on a 30 -year simulation for BY scenario.

\begin{tabular}{|c|c|c|c|}
\hline Type of delineation & Runoff (mm/year) & $\begin{array}{c}\text { Total N } \\
\text { (kg/ha/year) }\end{array}$ & Number of cells \\
\hline 1 & 184.5 & 11.3 & 48 \\
\hline 2 & 201.2 & 12.8 & 188 \\
\hline 3 & 190.6 & 11.3 & 367 \\
\hline 4 & 195.9 & 11.2 & 1728 \\
\hline
\end{tabular}


Table 7. Summary of simulation results for BY, BT and MS scenarios (results reported in the table are based on delineation 4).

\begin{tabular}{|c|l|c|c|}
\hline \multicolumn{2}{|c|}{ Scenarios } & \multicolumn{1}{|c|}{$\begin{array}{c}\text { Runoff } \\
\text { volume } \\
\text { (mm) }\end{array}$} & $\begin{array}{c}\text { Total N loading } \\
\text { (Kg/ha/year) }\end{array}$ \\
\hline BY & \multicolumn{1}{|c|}{ Base year } & 195.9 & 11.2 \\
\hline BY_1 & $\begin{array}{l}\text { All soybean (130.3 ha) represented 0.5\% of the } \\
\text { entire study area by AnnAGNPS converted to corn }\end{array}$ & 196.0 & 11.3 \\
\hline BY_2 & $\begin{array}{l}1 / 3 \text { of corn/soybean rotation }(5,290.4 \text { ha) } \\
\text { represented 18.4\% of the entire study area by } \\
\text { AnnAGNPS converted to continuous corn }\end{array}$ & 198.6 & 16.6 \\
\hline BY_3 & $\begin{array}{l}\text { 2/3 of corn/soybean rotation }(10,580.8 \text { ha) } \\
\text { represented 36.8\% of the entire study area by } \\
\text { AnnAGNPS converted to continuous corn }\end{array}$ & 201.3 & 21.8 \\
\hline BY_4 & $\begin{array}{l}\text { All corn/soybean rotation (15,871.2 ha) } \\
\text { represented 55.3\% of the entire study area by } \\
\text { AnnAGNPS converted to continuous corn }\end{array}$ & 196.6 & 24.9 \\
\hline BY_5 & $\begin{array}{l}\text { All fallow/idle (603.1 ha) represented } 2.1 \% \text { of the } \\
\text { entire study area by AnnAGNPS converted to corn }\end{array}$ & 197.4 & 25.7 \\
\hline MS-1 & Split fertilizer application & 197.4 & 21.1 \\
\hline
\end{tabular}

Figure 6. Total N loss for Base year delineations 4 and 1.
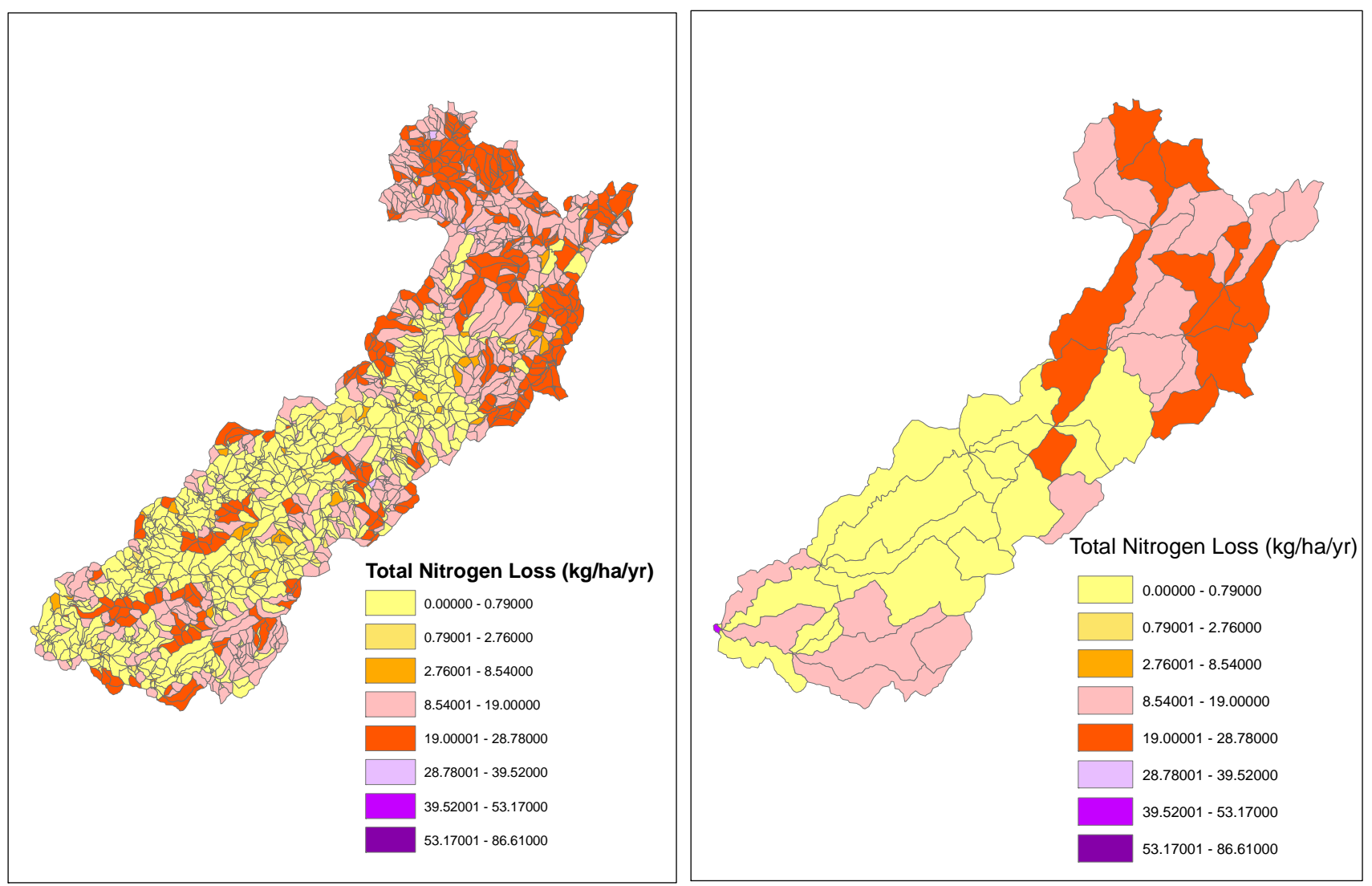
Figure 7. Total N loss for biofuel target scenario BT_5 (delineation 4).

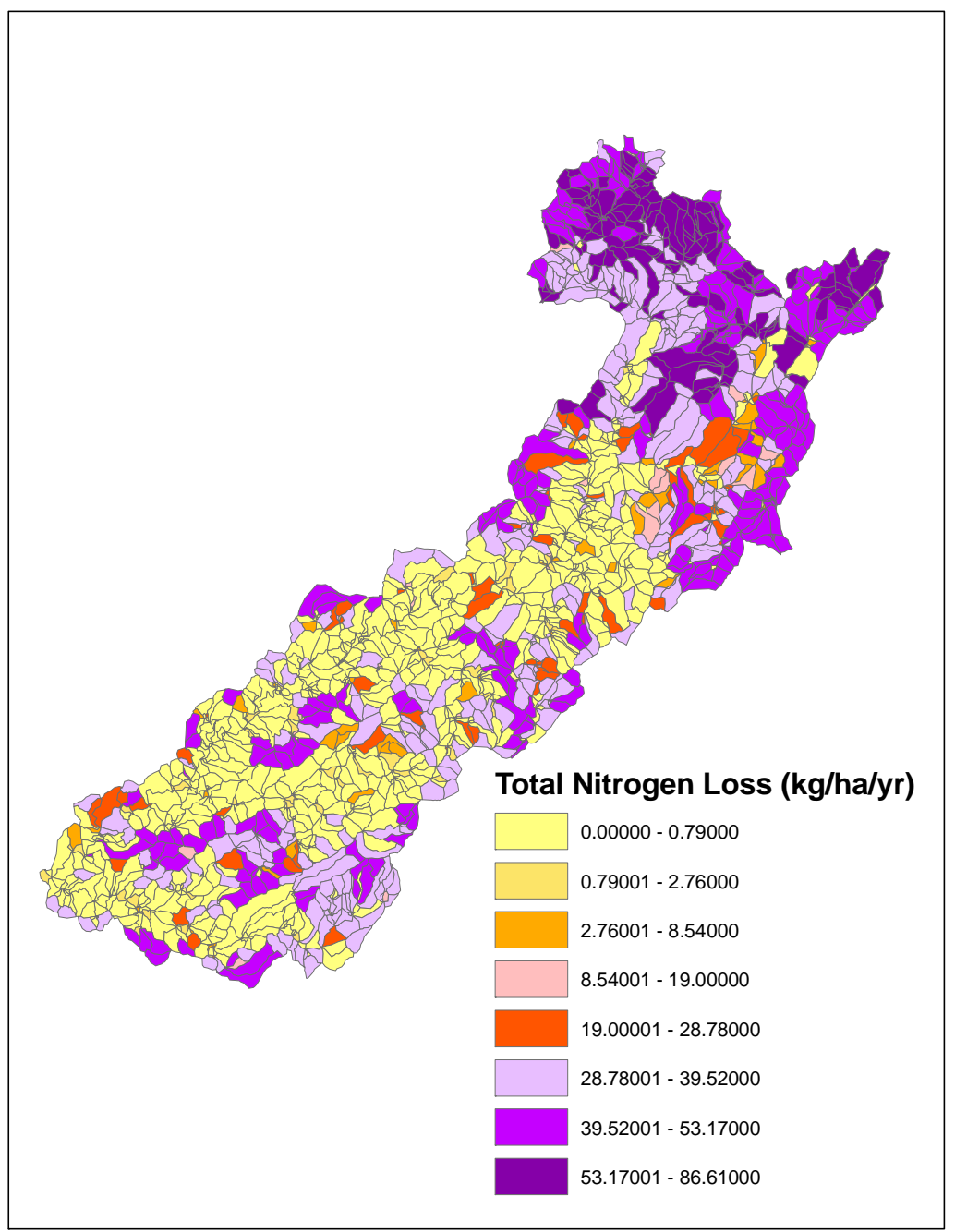

\subsection{Model Evaluation}

Comparisons between the simulated and observed monthly runoff at the USGS gauging station produced a NSE of 0.73 , RE of 0.1 and index of agreement ' $d$ ' of 0.91 (Figure 3). Comparisons between the simulated and observed annual runoff at the USGS gauging station produced a NSE of 0.76 , RE of 0.1 and index of agreement 'd' of 0.93 (Figure 4). Moriasi et al. [43] thoroughly reviewed literature on model application and recommended model evaluation methods, and they concluded that model simulation can be judged as satisfactory if NSE is greater than 0.50 ; very good if NSE is greater than 0.75 for runoff. Because of the overall good model performance as values of NSE, RE and index of agreement ' $d$ ' shown in Figures 3 and 4, no further model calibration was performed. This analysis reflects the capability of AnnAGNPS to estimate runoff that would be typical for ungauged watersheds, where data for calibration are usually not available. Furthermore, process based models are designed to characterize watershed processes well enough to enable the use of measurable properties and conditions without require formal calibration [44]. AnnAGNPS is one such model that has been developed to include processes that utilize input parameters from databases, e.g., climate, soil information, and crop management operations, developed by NRCS for any location in the U.S. This 
minimizes the user effort that would otherwise be necessary to acquire the information to calibrate or to apply AnnAGNPS for ungauged watersheds.

Comparisons of simulated monthly and annual runoff from other delineations (1, 2, and 3; Table 1) with observed monthly and annual runoff all produced satisfactory results (Table 5).

Comparisons between the model simulated annual total $\mathrm{N}$ loading and USGS observed annual total $\mathrm{N}$ loading which was actually calculated using the LOADEST program [29] did not produce as satisfactory results as the annual runoff (Figure 5). Generally, the annual total $\mathrm{N}$ loading was under predicted by AnnAGNPS model. The average annual USGS total N loading from 1980 to 2006 was $17.1 \mathrm{~kg} / \mathrm{ha} /$ year; while the model simulated average annual total $\mathrm{N}$ loading from 1980 to 2006 was $11.4 \mathrm{~kg} / \mathrm{ha} /$ year. In addition to the fact that point source pollution was not simulated, several other factors could have lead to the total $\mathrm{N}$ under-prediction. First, more $\mathrm{N}$ fertilizer may be applied than it was reported which was used for model input. Second, $N$ fertilizer may be applied in fall instead of spring which was assumed in the model simulations (Table 3). Third, under-predicted runoff could have lead to under-predicted total N. Finally, although the use of the USDA National Agriculture Statistical Survey (NASS) Cropland Data Layer (CDL) collected for years of 2004-2007 improved the NLCD land-use and cropping types and rotational information, there were still missing information on cropping types and rotational from 1980 to 2006 which could have lead to uncertainties in annual total $\mathrm{N}$ prediction. In addition, some uncertainties may also exist in LOADEST calculated USGS total N, which used the observed daily stream flow and monthly $\mathrm{N}$ concentrations. Concentrations measured once a month missed daily concentration changes happened during the month.

Total $\mathrm{N}$ loadings of nonpoint source from the urban-rural catchments in the Chesapeake Bay watershed range from 9.67 to $13.43 \mathrm{~kg} / \mathrm{ha} /$ year [45], and estimations of $\mathrm{N}$ loadings from the Upper Mississippi River basin ranged about 5 to $24 \mathrm{~kg} / \mathrm{ha} /$ year depending on the size of the watershed and cropping treatments [46]. AnnAGNPS N simulation is reasonable comparing with literature values.

Because of uncertainties related to model input data as well as the LOADEST program [29], further calibration was not performed. The long-term annual average were chosen to evaluate the BY, BT and MS scenarios because long-term average better reflects multi-year land-use and climate variability and helps assure that various conditions are covered.

\subsection{Watershed Simulation of Base Year}

The 30-year simulation of BY with AnnAGNPS produced an annual average runoff of $195.9 \mathrm{~mm}$, and annual average total $\mathrm{N}$ loss of $11.3 \mathrm{~kg} / \mathrm{ha}$ over the entire watershed (Table 6). Although all delineations produced satisfactory results for annual and monthly runoff simulation (Table 5), results of base year simulation from other delineations (Table 6) showed that the size of cells does impact the prediction results. The prediction results are impacted by how different delineations can accurately represent the actual land-use (Table 2). Delineation 4 represented the actual land-use more closely than the other three delineations (Table 2). However, the differences still exist between the real land-use and the land-use represented by delineation 4. For example, small percentage of land-use such as corn/wheat was not captured by delineation 4 . Delineation 2 produced the most amount of runoff because the delineation 2 had the most amount of cropland and the least amount of forest land (Table 2). In contrast, delineation 1 produced the least amount of runoff because the delineation 1 had 
the most amount of forest land (Table 2). Delineation 2 also produced the most amount of total N loss because of the most amount of cropland it represented. In addition, results of spatial variations are different. As shown in Figure 6, many small areas which produce high total $\mathrm{N}$ loadings in the lower part of the watershed would not be captured by delineation 1. For conservation practice implementation, those small critical areas may be important to target to achieve maximum environmental benefits.

As cell size increases (number of cells decreased), less detailed watershed information would be captured by the model. Therefore, it is assumed that delineation 4 produced the most accurate results because delineation 4 most closely represents the real land-use (Table 2). However, as delineations become finer and finer to capture more and more details of the watershed, more and more computational time and power are required. Thus, one has to balance between the level of detail a model represents and the computational limitation of a computer. For this study, it is assumed that delineation 4 captured sufficient details of the watershed to allow desired analysis to achieve the objectives of this study.

\subsection{Evaluation of Biofuel Target and Multiple Services Scenarios}

As given in Table 7, runoff showed very little change over all scenarios because both corn and soybeans are row crop and have the same curve number which is mainly used for runoff calculation in the model. However, as corn production increases, total $\mathrm{N}$ loss increases. Converting all soybean production (130.3 ha.) to corn (BT_1) would result in 1\% increase of total N; Converting one third of corn/soybean rotation $(5,290.4 \mathrm{ha})$ to continuous corn would result in $33 \%$ increase of total $\mathrm{N}$ loss. Total $\mathrm{N}$ loss would be more than doubled if converting all corn/soybean rotation $(15,871.2 \mathrm{ha})$ to continuous corn (BT_4 in Table 7) comparing with the base year total N loss. From BT_1 to BT_5, corn production increases, so does the total $\mathrm{N}$ loss. BT_5 TN loss is displayed in Figure 7 and it had an average of $25.7 \mathrm{~kg} / \mathrm{ha}$ (Figure 7).

Simulation results (Table 7) of MS_1 show that total $\mathrm{N}$ loss can be reduced by $20 \%$ by split $\mathrm{N}$ application (comparing MS_1 with BT_5). Therefore, additional management options must be sought to reduce total $\mathrm{N}$ loss from the study area. In addition to better management of $\mathrm{N}$ fertilization timing, $\mathrm{N}$ can be intercepted or transformed by using riparian buffer and in-stream wetlands. However, the model as run for this project did not have a riparian buffer and wetland component, thus, $\mathrm{N}$ benefits accrue from riparian and wetland could not be evaluated in this study. Further model enhancements are needed to include these features for future modeling of land-use scenarios.

Since much of the landscape assessment would be performed by models, given the difficulties of obtaining long-term monitoring data, application of AnnAGNPS model to evaluate the impact of future land-use changes in this study provides a good illustration of landscape assessment using watershed models. Although models are simplifications of the real world and uncertainty is an inevitable part of model simulation, through AnnAGNPS simulations of the alternative scenarios, relative impact of biofuel production can be compared which could be used as guidelines for future planning. 


\section{Conclusions}

AnnAGNPS runoff simulations of different delineations of watershed all produced satisfactory results comparing with the USGS observed runoff. However, cell size from different delineations does impact simulation results. The watershed should be delineated as detailed as possible within the computation power because finer delineations better represented the actual landscape and captured small critical areas that would be homogenized in coarser delineation. Those small critical areas are important to target to achieve maximum environment benefit. As corn production increases to meet future biofuel needs, total $\mathrm{N}$ loss increases. Simulations of split fertilizer application vs. one time application showed that split fertilizer application could reduce $\mathrm{N}$ loss by about $20 \%$. The model needs to be further enhanced to simulate additional conservation practices such as constructed wetland and riparian buffer for $\mathrm{N}$ loss reduction.

\section{Acknowledgements}

The authors are grateful for Jay Christensen who provided many valuable comments to improve the manuscript. Although this work was reviewed by USEPA and approved for publication, it may not necessarily reflect official Agency policy. Mention of trade names or commercial products does not constitute endorsement or recommendation for use.

\section{References}

1. Rabalais, N.N.; Turner, R.E.; Justic, D.; Dortch, Q.; Wiseman, J.W.; Sen Gupta, B.K. Nutrient changes in the Mississippi River and system response on the adjacent continental shelf. Estuaries 1996, 19, 385-407.

2. Rabalais, N.N.; Turner, R.E.; Justic, D.; Dortch, Q.; Wiseman, W.J., Jr.; Characterization of hypoxia: Topic 1 Report for the Integrated Assessment on Hypoxia in the Gulf of Mexico; NOAA Coastal Ocean Program Decision Analysis Series No. 16; NOAA Coastal Ocean Program: Silver Spring, MD, USA, 1999.

3. Aulenbach, B.T.; Buxton, H.T.; Battaglin, W.A.; Coupe, R.H. Stream Flow and Nutrient Fluxes of the Mississippi-Atchafalaya River Basin and Subbasins for the Period of Record through 2005; U.S. Geological Survey Open-File Report 2007-1080. Available online: http://toxics.usgs.gov/ pubs/of-2007-1080/index.html (accessed on 8 June 2009).

4. Booth, M.S.; Campbell, C. Spring nitrate flux in the Mississippi River Basin: A landscape model with conservation applications. Environ. Sci. Technol. 2007, 41, 5410-5418.

5. U.S. Environmental Protection Agency Science Advisory Board. Hypoxia in the Northern Gulf of Mexico: An Update by the EPA Science Advisory Board. Available online: http://www.epa.gov/ $\mathrm{msbasin} / \mathrm{pdf} / \mathrm{sab}$ _report_2007.pdf (accessed on 10 September 2009).

6. National Primary Drinking Water Regulations: Maximum Contaminant Levels and Maximum Residual Disinfectant Levels; In Subpart G of Code of Federal Regulations, Title 40, Parts 100-149: 559-563; U.S. Environmental Protection Agency: Washington, DC, USA, 2008. 
7. Mitsch, W.J.; Day, J.W., Jr.; Gilliam, J.W.; Groffman, P.M.; Hey, D.L.; Randall, G.W.; Wang, N. Reducing nitrogen loading to the Gulf of Mexico from the Mississippi River Basin: Strategies to counter a persistent ecological problem. BioScience 2001, 51, 373-388.

8. Crumpton, W.G.; Stenback, G.A.; Miller, B.A.; Helmers, M.J. Potential Benefits of Wetland Filters for Tile Drainage System: Impact on Nitrate Loads to Mississippi River Subbasins; Final project report to U.S. Department of Agriculture, Project number: IOW06682; U.S. Department of Agriculture: Washington, DC, USA, 2007.

9. Lovanna, R.; Hyberg, S.; Crupton, W. Treatment wetlands: Cost-effective practice for intercepting nitrate before it reaches and adversely impacts surface waters. J. Soil Water Conserv. 2008, 63, $14 \mathrm{~A}-15 \mathrm{~A}$.

10. Shih, G.; Abtew, W.; Obeysekera, J. Accuracy of nutrient runoff load calculations using time-composite sampling. Trans. ASAE 1994, 37, 419-429.

11. Stone, K.C.; Hunt, P.G.; Novak, J.M.; Johnson, M.H.; Watts, D.W. Flow-proportional, time-composited, and grab sample estimation of nitrogen export from an eastern coastal plain watershed. Trans. ASAE 2000, 43, 281-290.

12. Borah, D.K.; Bera, M.; Shaw, S. Water, sediment, nutrient, and pesticide measurements in an agricultural watershed in Illinois during storm events. Trans. ASAE 2003, 46, 657-674.

13. Bingner, R.L.; Theurer, F.D.; Yuan, Y. AnnAGNPS Technical Processes 2003. Available online: http://www.ars.usda.gov/Research/docs.htm?docid=5199 (accessed on 10 March 2010).

14. Yuan, Y.; Bingner, R.L.; Rebich, R.A. Evaluation of AnnAGNPS on Mississippi Delta MSEA Watersheds. Trans. ASAE 2001, 45, 1183-1190.

15. Yuan, Y.; Bingner, R.L.; Rebich, R.A. Evaluation of AnnAGNPS nitrogen loading in an agricultural watershed. J. American Water Res. Assoc. 2003, 39, 457-466.

16. Suttles, J.B.; Vellidis, G.; Bosch, D.; Lowrance, R.; Sheridan, J.M.; Usery, E.L. Watershed-scale simulation of sediment and nutrient loads in Georgia Coastal Plain streams using the Annualized AGNPS model. Trans. ASAE 2003, 46, 1325-1335.

17. Baginska, B.; Milne-Home, W.; Cornish, P.S. Modeling nutrient transport in Currency Creek, NSW with AnnAGNPS and PEST. Environ. Model. Softw. 2003, 18, 801-808.

18. Shrestha, S.; Mukand, S.B.; Gupta, A.D.; Kazama, F. Evaluation of annualized agricultural nonpoint source model for a watershed in the Siwalik Hills of Nepal. Environ. Model. Softw. 2006, 21, 961-975.

19. Licciardello, F.; Zema, D.A.; Zimbone, S.M.; Bingner, R.L. Runoff and soil erosion evaluation by the AnnAGNPS model in a small Mediterranean watershed. Trans. ASAE 2007, 50, 1585-1593.

20. Young, R.A.; Onstad, C.A.; Bosch, D.D.; Anderson, W.P. AGNPS: A nonpoint-source pollution model for evaluating agricultural watersheds. J. Soil Water Conserv. 1989, 44, 168-173.

21. USDA Soil Conservation Service (SCS). National Engineering Handbook. Section 4: Hydrology; U.S. Department of Agriculture: Washington DC, USA, 1985.

22. Penman, H.L. Natural evaporation from open water, bare soil, and grass. Proc. Royal Soc. A 1948, 193, 120-145.

23. Evapotranspiration and Irrigation Water Requirements. In ASCE Manuals and Reports on Engineering Practice, No. 70.; Jenson, M.E., Burman, R.D., Allen, R., Eds.; ASCE (American Society of Civil Engineers): Reston, VA, USA, 1990; pp. 311-327. 
24. Freeze R.A.; Cherry, J.A. Groundwater; Prentice Hall: Englewood Cliffs, NJ, USA, 1979.

25. Smedema, L.K.; Rycroft, D.W. Land Drainage; Cornell University Press: Ithaca, NY, USA, 1983.

26. Yuan, Y.; Bingner, R.L.; Theurer, F.D. Subsurface flow component for AnnAGNPS. Appl. Eng. Agric. 2006, 22, 231-241.

27. Arnold, J.G.; Allen, P.M.; Muttiah, R.; Bernhardt, G. Automated base flow separation and recession analysis techniques. Ground Water 1995, 33, 1010-1018.

28. Arnold, J.G.; Allen, P.M. Automated methods for estimating baseflow and groundwater recharge from streamflow records. J. Am. Water Resour. Assoc. 1999, 35, 411-424.

29. Runkel, R.L.; Crawford, C.G.; Cohn, T.A. Cohn Load Estimator (LOADEST): A FORTRAN Program for Estimating Constituent Loads in Streams and Rivers; Techniques and Methods Book 4, Chapter A5; U.S. Geological Survey: Reston, VA, USA, 2004.

30. Renard, K.G.; Foster, G.R.; Weesies, G.A.; McCool, D.K.; Yoder, D.C. (coordinators). Predicting Soil Erosion by Water: A Guide to Conservation Planning with the Revised Universal Soil Loss Equation (RUSLE); Agriculture Handbook No. 703. U.S. Department of Agriculture: Washington, DC, USA, 1997.

31. Johnson, G.L.; Daly, C.; Taylor, G.H.; Hanson, C.L. Spatial variability and interpolation of stochastic weather simulation model parameters. J. Appl. Meteorol. 2000, 39, 778-796.

32. Martz, L.W.; Garbrecht, J. Numerical definition of drainage network and subcatchment areas from Digital Elevation Models. Comput. Geosci. 1992, 18, 747-761.

33. Mark, D.M. Automatic detection of drainage networks from Digital Elevation Models. Cartographica 1984, 21, 168-178.

34. Natural Resources Conservation Service (NRCS). Soil Survey Geographic (SSURGO) Database 2009. Available online: http:/www.soils.usda.gov/survey/geography/ssurgo/ (accessed on 15 January 2009).

35. Stevenson, F.J. Humus Chemistry: Genesis, Composition, Reactions; John Wiley \& Sons, Inc.: New York, NY, USA, 1994.

36. U.S. Geological Survey (USGS). National Water Information System. Available online: http://waterdata.usgs.gov/i1/nwis/help/?provisional (accessed on May 4, 2009).

37. National Sedimentation Laboratory. Generating Climate Data for AnnAGNPS 2007. Available Online: http://www.ars.usda.gov/Research/docs.htm?docid=5199 (accessed on 8 January 2010).

38. Daly, C.; Taylor, G.H.; Gibson, W.P. The PRISM approach to mapping precipitation and temperature. Available on line: http://www.prism.oregonstate.edu/pub/prism/docs/appclim97prismapproach-daly.pdf (accessed on 15 February 2011).

39. Nash, J.E.; Sutcliffe, J.V. River flow forecasting through conceptual models: Part I. A discussion of principles. J. Hydrology 1970, 10, 282-290.

40. Willmott, C.J. On the Evaluation of Model Performance in Physical Geography. In Spatial Statistics and Models; Gaile, G.L., Willmott, C.J., Eds.; Springer: Boston, MA, USA, 31 March 1984; pp. 443-460.

41. Schurman, C. Side-dressing \& Foliar Feeding $P \& K$ Options. Available online: http://www.brownfertilizer.com/sidedressing_foliaroptions-may09.doc (accessed on 13 August 2009). 
42. Rode, M.; Suhr, U. Uncertainties in selected river water quality data. Hydrol. Earth Syst. Sci. 2007, 11, 863-874.

43. Moriasi, D.N.; Arnold, J.G.; Liew, M.W.; Bingner, R.L.; Harmel, R.D.; Veith, T. Model evaluation guidelines for systematic quantification of accuracy in watershed simulations. Trans. ASAE 2007, 50, 885-900.

44. Baginska, B.; Milne-Home, W.A. Parameter Sensitivity in Calibration and Validation of an Annualized Agricultural Non-Point Source Model. In Calibration of Watershed Models; Duan, Q., Gupta, H.V., Sorooshian, S., Rousseau, A.N., Turcotte, R., Eds.; American Geophysical Union: Washington, DC, USA, 2003.

45. Shields, C.A.; Band, L.E.; Law, N.; Groffman, P.M.; Kaushal, S.S.; Savvas, K.; Fisher, G.T.; Belt, K.T. Streamflow distribution of non-point source nitrogen export from urban-rural catchments in the Chesapeake Bay watershed. Water Resour. Res. 2008, 44, W09416.

46. Turner, R.E.; Rabalais, N.N. Linking landscape and water quality in the Mississippi River Basin for 200 years. BioScience 2003, 53, 563-572.

(C) 2011 by the authors; licensee MDPI, Basel, Switzerland. This article is an open access article distributed under the terms and conditions of the Creative Commons Attribution license (http://creativecommons.org/licenses/by/3.0/). 